\title{
Penetapan Kebutuhan Vitamin E ( $\alpha$-Tocopherol) pada Berbagai Fase Produksi Induk (Gestasi dan Laktasi) dan Kelinci Lepas Sapih
}

\section{(Determination of Vitamin E ( $\alpha$-Tocopherol) Requirements at Various Phases of Production (Gestation and Lactation) and Weaning Rabbit)}

\author{
Haryati T, Soewandi BDP, Raharjo Y \\ Balai Penelitian Pernak, PO Box 221, Ciawi, Bogor 16002 \\ purringcats2001@yahoo.com.au
}

\begin{abstract}
Vitamin E or $\alpha$-tocopherol is an antioxidant that plays a role in maintaining the stability of cell membranes from oxidation of unsaturated fats are also influential in enhancing the immune response to the disease and improve cow fertility. The experiments were conducted on pregnant New Zealand White (NZW), nursing and growing rabbits. Sources of vitamin E that is used is commercial vitamin $\mathrm{E}$ and/or sprouts. Research laboratory with seven treatment levels of vitamin $\mathrm{E}$ $0,50,100,150,200,250$, and $300 \mathrm{mg} / \mathrm{kg}$ of feed. Every treatment using $10-15$ of does with three parity. Six to ten replication for weaning phase with three heads per replication for eight weeks. For sperm quality evaluation were using five bucks and were collected five times in every three days per treatment. Growth rate evaluation on does were the reproductive performance (level of receptivity, conception rate, birth litter size (LS), LS weaning, the weight of does, weight at age three weeks, weaning weight, mortality and lactation, the frequency of abortion). In the kits growth measurements were performed on body weight gain, consumption, feed conversion, mortalites. Results showed that the highest LS (nine heads) that is on the supplementaion treatment with 100 $\mathrm{mg} / \mathrm{kg}$ or equivalent with $200 \mathrm{mg}$ vitamin $\mathrm{E} / \mathrm{kg}$ of feed), up to 35 days of ages all treatments can keep their kits above six heads. The best milk production produced by the treatment of the addition of 50 and $100 \mathrm{mg}$ vitamin $\mathrm{E} / \mathrm{kg}$ or equivalent with 200 and $300 \mathrm{mg}$ vitamin $\mathrm{E} / \mathrm{kg}$ which is 1,660 and $1,585 \mathrm{~g} / \mathrm{heads} / 21$ days. It can be concluded that vitamin $\mathrm{E}$ supplementation in feed rabbits by $50-100 \mathrm{mg} / \mathrm{kg}$ or equivalent with 200 and $300 \mathrm{mg}$ vitamin E/ $/ \mathrm{kg}$ can increase LS, mother's milk production and survival of kits.
\end{abstract}

Key Words: Vitamin E, Requirement, Rabbit

\begin{abstract}
ABSTRAK
Vitamin $\mathrm{E}$ atau $\alpha$-tocopherol merupakan antioksidan yang berperan dalam menjaga stabilitas membran sel dari oksidasi lemak tak jenuh juga berpengaruh dalam meningkatkan respon kekebalan tubuh terhadap penyakit dan meningkatkan fertilitas ternak. Percobaan dilakukan terhadap kelinci jenis New Zealand White (NZW) sedang bunting, menyusui dan pertumbuhan. Sumber vitamin E yang digunakan yaitu vitamin E komersial dan/atau kecambah. Penelitian laboratorium dengan tujuh perlakuan tingkat vitamin E: 0, 50, 100, 150, 200, 250 dan $300 \mathrm{mg} / \mathrm{kg}$ pakan. Setiap perlakuan menggunakan 10-15 induk dengan tiga paritas. Pada kelinci lepas sapih sejumlah 6-10 replikasi, masing-masing tiga ekor selama delapan minggu dan pada pejantan, sejumlah lima pejantan dengan koleksi sperma masing-masing lima kali setiap tiga hari/perlakuan. Pengamatan dilakukan pada induk adalah kinerja reproduksi (tingkat receptivity, tingkat konsepsi, litter size (LS) lahir, LS sapih, bobot induk, anak lahir, bobot umur tiga minggu, bobot sapih, mortalitas dan laktasi, frekuensi abortus). Pengukuran pertumbuhan anak dilakukan pada bobot badan, konsumsi, konversi ransum dan mortalitas. Hasil menunjukan LS yang tertinggi sembilan ekor yaitu pada perlakuan pemberian $100 \mathrm{mg}$ vitamin E/kg pakan. Sampai umur 35 hari semua perlakuan dapat mempertahankan anak di atas enam ekor. Produksi susu yang baik dihasilkan oleh perlakuan penambahan 50 dan $100 \mathrm{mg}$ vitamin E/kg pakan atau setara kandungan 200 dan $300 \mathrm{mg} / \mathrm{kg}$ yaitu 1.660 dan $1.585 \mathrm{~g} / \mathrm{ekor} / 21$ hari. Dapat disimpulkan bahwa suplementasi vitamin E pada pakan
\end{abstract}


kelinci sebesar 50-100 mg/kg atau setara kandungan 200 dan $300 \mathrm{mg} / \mathrm{kg}$ dapat meningkatkan LS, produksi susu induk dan daya tahan hidup anak.

Kata Kunci: Kelinci, Vitamin E, Kebutuhan, Kelinci

\section{PENDAHULUAN}

Suplementasi vitamin E umum dilakukan untuk meningkatkan pertumbuhan dan kesehatan ternak serta karakteristik tertentu yang dibutuhkan. Strategi ini efektif untuk meningkatkan fungsi reproduksi ternak dimana germ sel mudah sekali rusak karena oksidasi sehingga diperlukan penambahan antioksidan (Castellini et al. 2007).

Pada peternakan komersial untuk menghindari defisiensi vitamin E, dilakukan suplementasi wheat germ oil. Pemberian vitamin E dengan dosis tinggi $(120 \mathrm{mg} / \mathrm{kg})$ secara nyata menghasilkan pertambahan bobot badan yang tinggi serta konversi pakan yang baik (El-Medany et al. 2012). Di Balai Penelitian Ternak (Balitnak) saat ini, jarak beranak masih cukup panjang berkisar antara 49-83 hari, laju kebuntingan rendah $(<60 \%)$, dengan insiden aborsi yang sering terjadi. Tingginya tingkat still birth (lahir mati) $(\leq 7 \%)$ dan kasus resorpsi fetus yang terjadi dan mortalitas saat laktasi (5-15\%), diduga disebabkan antara lain oleh kurangnya tingkat vitamin E dalam ransum. Informasi kebutuhan vitamin E untuk kelinci saat ini masih berupa estimasi dan untuk kondisi tropik kebutuhan tersebut mungkin lebih tinggi dari nilai rekomendasi selama ini.

Berbagai bahan lokal yang mempunyai kandungan vitamin E yang tinggi seperti kecambah dapat digunakan untuk suplementasi vitamin $\mathrm{E}$ sehingga kebutuhan vitamin $\mathrm{E}$ pada ternak dapat terpenuhi. Kelinci adalah ternak herbivore prolific yang dapat memproduksi anak dalam jumlah banyak per kelahiran, terutama pada kelinci hibrida (litter size (LS) berkisar antara 6-13 ekor). Namun pada kondisi saat ini, di peternakan kelinci di Indonesia sering dijumpai kasus kegagalan reproduksi, seperti abortus dan mortalitas yang cukup tinggi saat laktasi. Salah satu penyebab diperkirakan dari ketidak cukupan ketersediaan vitamin E dalam pakan.

Vitamin $\mathrm{E}$ atau $\alpha$-tocopherol merupakan antioksidan intraseluler yang berfungsi menghambat terjadinya keracunan peroksida lemak, berperan dalam menjaga stabilitas membran sel dari oksidasi lemak tak jenuh juga berperan dalam meningkatkan respon kekebalan tubuh terhadap penyakit dan meningkatkan fertilitas ternak. Tocopherol berarti bearing off springs atau berhubungan erat dengan kemampuan untuk menghasilkan keturunan dalam jumlah besar. Defisiensi vitamin E menyebabkan hemolisis erythrocyte, degenerasi lipid dan distrophy otot (Scott etal. 1982) yang berakibat pada masalah reproduksi seperti fertilitas rendah, degenerasi embrio, resorpsi fetus, bayi prematur, kesterilan pada jantan dan post partum mortality (Cheeke 1987). Hal ini ditunjukkan pada tingginya tingkat lahir mati, infertilitas (LI yang lama), abortus, resorpsi fetus. Selain itu, fungsi dari vitamin $\mathrm{E}$ ini sangat berkaitan dengan mineral selenium, dimana keduanya berperan dalam pencegahan oksidasi sel dan sistim imunitas. Menurut Cheeke et al. (1987) bahwa khusus kelinci, pengaruh vitamin E lebih besar daripada interaksinya dengan selenium.

Estimasi kebutuhan vitamin E yang direkomendasikan adalah sekitar 40 ppm (NRC 1977) hingga 50 ppm (Lebas 1980) disajikan pada Tabel 1. Namun dengan suplementasi 100 ppm vitamin E di dalam pakan di Balitnak, kasus-kasus kegagalan reproduksi masih sering dijumpai terutama mortalitas saat laktasi awal, terutama saat musim hujan (Raharjo 2015, komunikasi pribadi). Suplementasi vitamin E >200 ppm dapat meningkatkan kualitas daging. Kelinci yang pakannya disuplementasi vitamin E tinggi mempunyai kualitas daging yang lebih stabil dan dripping losses-nya lebih kecil (Benardini et al. 1996). 
Tabel 1. Kebutuhan vitamin E (IU/kg) pada kelinci pada berbagai fase

\begin{tabular}{lcc}
\hline \hline Fase & NRC (1977) & Lebas (1980) \\
\hline Pertumbuhan & 40 & 50 \\
Maintenance & - & 50 \\
Bunting & 40 & 50 \\
Menyusui & 40 & 50 \\
\hline
\end{tabular}

Penggunaan vitamin E dalam pakan perlu memperhatikan jenis dan tingkat serat kasar dalam ransum, karena dapat berpengaruh pada absorpsi vitamin E di dalam usus. Selain itu, vitamin E sensitif terhadap oksidasi dan mudah rusak karena panas, cahaya dan kelembaban (Scott et al. 1982) yakni kondisi yang umum terdapat di negara tropis. Proses pembuatan pelet untuk pakan kelinci yang melibatkan panas, menambah kerusakan pada vitamin E. Oleh karena itu, dalam menentukan kebutuhan vitamin E, hal-hal tersebut perlu mendapat perhatian. Vitamin E banyak didapat pada hijauan tertentu, minyak yang berasal dari biji-bijian dan minyak ikan, minyak tanaman (minyak jagung, minyak kedelai dan minyak lembaga gandum) (Scott et al. 1982), serta pada kecambah. Dalam ransum kelinci di negara subtropis, vitamin E diperoleh dari alfalfa (mencapai $150 \mathrm{mg} / \mathrm{kg}$ ), sedangkan di negara tropis seperti di Indonesia hampir sepenuhnya diperoleh dari suplementasi.

Penambahan kecambah pada taraf tertentu, mungkin dapat dibandingkan dnegan penggunaan vitamin E. Selain itu, karena berupa kecambah segar, ketersediaan dan absorpsinya diperkirakan lebih efektif dan juga kecambah dapat meningkatkan sedikit kandungan protein dan serat. Tujuan dari penelitian ini adalah menghasilkan tingkat kebutuhan vitamin E yang tepat, bahkan jika memungkinkan sampai ke tingkat kebutuhan vitamin $\mathrm{E}$ tercerna.

\section{MATERI DAN METODE}

Penelitian dilakukan pada tahun 2015 di Stasiun Kandang Percobaan Kelinci di Balai Penelitian Ternak, Ciawi, Bogor. Ternak kelinci yang digunakan adalah jenis New Zealand White (NZW) yang sedang bunting, menyusui dan proses pertumbuhan. Sumber vitamin E yang digunakan yaitu vitamin E komersial dan/atau kecambah.

Penelitian laboratorium dilakukan dengan perlakuan tujuh tingkat vitamin E 0,50 , 100, 150, 200, 250 dan $300 \mathrm{mg} / \mathrm{kg}$ pakan pada induk NZW. Setiap perlakuan menggunakan 10-15 induk dengan tiga paritas. Pada kelinci lepas sapih sejumlah 6-10 replikasi, masing-masing tiga ekor selama delapan minggu dan pada pejantan, sejumlah lima pejantan dengan koleksi sperma masing-masing lima kali setiap tiga hari per perlakuan. Pemberian kecambah dilakukan hanya dengan satu tingkat, setara $200 \mathrm{mg} / \mathrm{kg}$ dalam pakan dan diberikan segar, dilakukan hanya pada dua paritas dengan ulangan 10-15 induk. Kandungan vitamin E dalam ransum disajikan pada Tabel 2.

Tabel 2. Kandungan vitamin E dalam ransum

\begin{tabular}{lcccccccc}
\hline \hline \multirow{2}{*}{ Ransum } & \multicolumn{8}{c}{ Perlakuan } \\
\cline { 2 - 8 } & $1 / 0$ (basal) & $2 / 50$ & $3 / 100$ & $4 / 150$ & $5 / 200$ & $6 / 250$ & $7 / 300$ & Kecambah \\
\hline $\begin{array}{l}\text { Kandungan vit. E } \\
\text { (mg/kg)* }\end{array}$ & 151 & 199 & 283 & 342 & 399 & 424 & 729 & 0,1 \\
\hline
\end{tabular}

*: Hasil analisis 
Pengukuran produksi susu dilakukan menggunakan metode tidak langsung yaitu dengan mengestimasi melalui perbedaan bobot badan anak lahir sampai umur 21 hari. Hasil analisis vitamin $\mathrm{E}$ dalam pakan menunjukan ransum $1 / 0$ atau kontrol basal mempunyai kandungan vitamin E $151 \mathrm{mg} / \mathrm{kg}$, untuk ransum perlakuan 2, 3, 4, 5 dan 6 masih dalam kisaran nilai kandungan dalam basal ditambah penambahan sesuai perlakuan kecuali ransum perlakuan 7 atau perlakuan $7 / 300$ jauh di atas nilai yang semestinya. Kandungan vitamin E dalam kecambah yang dianalisis sangat rendah sekali karena mungkin kecambah yang dipakai yaitu kecambah panjang bukan kecambah pendek.

Pengamatan yang dilakukan pada induk adalah kinerja reproduksi meliputi tingkat receptivity, tingkat konsepsi, LS lahir, LS sapih, bobot induk, jumlah anak lahir, bobot umur tiga minggu, bobot sapih, mortalitas saat lahir dan laktasi. Pada pertumbuhan anak pengukuran dilakukan pada bobot badan, konsumsi, konversi ransum, mortalitas mingguan, kualitas karkas/daging. Data dianalisis menggunakan rancangan acak lengkap (RAL) dengan bantuan software SPSS IBM 20.

\section{HASIL DAN PEMBAHASAN}

Hasil analisis statistik menunjukkan bahwa perlakuan tidak memberikan pengaruh yang nyata terhadap konsumsi efisiensi pakan, pertambahan bobot badan dan mortalitas kelinci lepas sapih (Tabel 3). Kematian ternak selama penelitian hanya sedikit, berkisar 0tiga ekor pada semua perlakuan. Pada pemberian vitamin E $100 \mathrm{mg} / \mathrm{kg}$ pakan tidak terdapat kematian ternak. Hal ini bisa dikaitkan dengan produksi susu (Tabel 6) yang menunjukkan induk kelinci dengan perlakuan 50 dan $100 \mathrm{mg} / \mathrm{kg}$ pakan menghasilkan susu yang baik. Produksi susu sangat berpengaruh terhadap bobot badan dan daya hidup anak.

Tabel 3. Kinerja kelinci lepas sapih selama pemeliharaan sembilan minggu

\begin{tabular}{lccccc}
\hline \hline Perlakuan & BB $0(\mathrm{~g})$ & Konsumsi $(\mathrm{g})$ & FCR & PBB $(\mathrm{g})$ & Mortalitas \\
\hline $1 / 0$ & 801 & 13.477 & 3,56 & 3.805 & 2 \\
$2 / 50$ & 958 & 13.698 & 4,56 & 3.115 & 1 \\
$3 / 100$ & 980 & 14.560 & 3,44 & 4.242 & 0 \\
$4 / 150$ & 1002 & 12.140 & 4,22 & 2.930 & 3 \\
$5 / 200$ & 812 & 12.557 & 3,97 & 3.245 & 2 \\
$6 / 250$ & 942 & 12.462 & 4,01 & 3.313 & 1 \\
$7 / 300$ & 937 & 12.392 & 5,58 & 2.330 & 3 \\
\hline
\end{tabular}

Tabel 4. Bobot badan induk selama periode kawin sampai sapih

\begin{tabular}{|c|c|c|c|c|c|c|c|}
\hline \multirow{2}{*}{ Perlakuan } & \multicolumn{2}{|c|}{ Kawin } & \multicolumn{2}{|c|}{ Palpasi } & \multirow{2}{*}{ Lahir } & \multirow{2}{*}{21 hari } & \multirow{2}{*}{35 hari } \\
\hline & & $\mathrm{SD}$ & & $\mathrm{SD}$ & & & \\
\hline $1 / 0$ & 3.527 & 460 & 3.709 & 507 & $3.687^{\mathrm{ab}}$ & $3.552^{\mathrm{ab}}$ & $3.337^{\mathrm{b}}$ \\
\hline $2 / 50$ & 3.497 & 520 & 3.506 & 582 & $3.596^{\mathrm{ab}}$ & $3.617^{\mathrm{ab}}$ & $3.401^{\mathrm{ab}}$ \\
\hline $3 / 100$ & 3.803 & 539 & 3.943 & 522 & $4.009^{\mathrm{b}}$ & $3.882^{\mathrm{b}}$ & $3.701^{b}$ \\
\hline $4 / 150$ & 3.506 & 563 & 3.690 & 527 & $3.660^{\mathrm{ab}}$ & $3.545^{\mathrm{ab}}$ & $3.433^{\mathrm{ab}}$ \\
\hline $5 / 200$ & 3.607 & 454 & 3.870 & 425 & $3.753^{\mathrm{ab}}$ & $3.716^{\mathrm{ab}}$ & $3.574^{\mathrm{b}}$ \\
\hline $6 / 250$ & 3.779 & 631 & 3.877 & 599 & $3.767^{\mathrm{ab}}$ & $3.855^{\mathrm{b}}$ & $3.598^{\mathrm{b}}$ \\
\hline $7 / 300$ & 3.533 & 669 & 3.819 & 637 & $3.739^{\mathrm{ab}}$ & $3.714^{\mathrm{ab}}$ & $3.521^{\mathrm{b}}$ \\
\hline Kecambah & 3.226 & & 3.289 & & $3.172^{\mathrm{a}}$ & $3.190^{\mathrm{a}}$ & $293^{7 \mathrm{a}}$ \\
\hline
\end{tabular}

Superskrip yang berbeda pada kolom yang sama menunjukkan berbeda nyata $(\mathrm{P}<0,05)$ 
Bobot badan induk akan meningkat sejalan dengan kebuntingan (Tabel 4), bobot badan induk bunting akan berkaitan dengan jumlah anak atau berat anak yang dilahirkan. Jumlah anak sekelahiran rata-rata antara 7,4-9 ekor, pemeliharaan sampai 35 hari anak yang bertahan hidup masih di atas enam ekor, kematian yang terjadi $\leq 10 \%$. Hal ini selain karena pengaruh pakan juga pengaruh dari sistem pemeliharaan serta kondisi lingkungan atau kandang.

Tabel 5. Daya tahan hidup (ekor) litter size

\begin{tabular}{|c|c|c|c|c|c|c|c|}
\hline \multirow{2}{*}{ Perlakuan } & \multicolumn{2}{|c|}{ Lahir } & \multicolumn{2}{|c|}{21 hari } & \multicolumn{2}{|c|}{35 hari } & \multirow{2}{*}{ Lama bunting (hari) } \\
\hline & Hidup & Mati & Hidup & Mati & Hidup & Mati & \\
\hline $1 / 0$ & 7,9 & 0,7 & 6,2 & 2,0 & 5,9 & 0,5 & 32,1 \\
\hline $2 / 50$ & 9,3 & 0,2 & 7,1 & 1,5 & 7,0 & 0,2 & 32,0 \\
\hline $3 / 100$ & 8,6 & 0,1 & 6,9 & 1,3 & 6,4 & 0,5 & 32,6 \\
\hline $4 / 150$ & 8,6 & 0,1 & 7,2 & 1,2 & 6,7 & 0,4 & 31,8 \\
\hline $5 / 200$ & 8,9 & 0,5 & 7,3 & 1,3 & 6,9 & 0,4 & 32,0 \\
\hline $6 / 250$ & 8,4 & 0,5 & 6,8 & 1,3 & 6,1 & 0,6 & 32,1 \\
\hline $7 / 300$ & 8,2 & 0,1 & 7,1 & 1,3 & 6,7 & 0,4 & 32,3 \\
\hline kecambah & 8,8 & 0,2 & 7,3 & 0,7 & 7,1 & 0,6 & 32,1 \\
\hline
\end{tabular}

Lama kebuntingan dari semua perlakuan rata-rata berkisar dari 31,9-32,2 hari. Secara umum lama kebuntingan dari kelinci NZW berkisar antara 30,4 hingga 33,0 hari (Tawfeek \& El-Gaafary 1991; Yamani et al. 1994; Gad Alla et al. 2002). Hal ini menunjukkan perlakuan pemberian suplemen vitamin $\mathrm{E}$ tidak berpengaruh terhadap lamanya kebuntingan.

\section{Performa pertumbuhan anak dan produksi susu induk kelinci}

Terdapat korelasi yang tinggi antara produksi susu dengan pertumbuhan anak (Tabel 6). Anak kelinci tidak menunjukkan konsumsi pakan yang signifikan sebelum usia 18-19 hari (Fortun-Lamothe \& Gidenne 2000). Korelasi tertinggi yang dilaporkan adalah untuk periode antara kelahiran dan 21 hari usia dan jumlah 0,90 (Lebas 1969). Berat badan anak 21 hari dapat digunakan untuk memprediksi produksi susu induk.

Faktor non-gizi yang memiliki dampak terbesar pada produksi susu adalah jumlah anak menyusui, urutan paritas dan tingkat kebuntingan yang tumpang tindih (17-20 hari). Kurangnya konsumsi pakan mengakibatkan stres karena panas terutama ketika suhu malam tetap di atas $25^{\circ} \mathrm{C}$. (Maertens et al. 2006). Produksi perlu diperhatikan untuk program seleksi karena akan berkaitan dengan bobot anak, daya tahan hidup anak dan pertumbuhan lepas sapih.

Pertumbuhan anak selama pemeliharaan 35 hari menunjukkan perlakuan pemberian vitamin E 50 dan $100 \mathrm{mg} / \mathrm{kg}$ pakan merupakan yang lebih baik dibandingkan dengan perlakuan lainnya. Hal ini juga sesuai dengan LS yang dihasilkan serta produksi susu (Tabel 5 dan 6).

Analisis karkas kelinci jantan pada akhir penelitian menunjukkan suplementasi vitamin E tidak berpengaruh terhadap karkas dan organ dalam kecuali bobot ginjal (Tabel 7). Tidak dilakukan analisis kualitas daging. Penelitian Kowalska \& Bielański (2009) menunjukkan suplementasi minyak ikan dengan vitamin E pada pakan kelinci berpengaruh terhadap kualitas daging, penambahan vitamin E dengan level yang lebih tinggi akan meningkatkan deposit vitamin E dalam daging sehingga dapat mencegah terjadinya proses 
oksidasi lemak daging selama penyimpanan. Suplemen minyak ikan memiliki efek yang menguntungkan pada penurunan lemak karkas dan meningkatkan kelembapan dan keempukan daging kelinci.

Tabel 6. Bobot anak (g) selama pemeliharaan 35 hari dan produksi susu induk

\begin{tabular}{|c|c|c|c|c|c|c|c|}
\hline \multirow{2}{*}{ Perlakuan } & \multicolumn{2}{|c|}{ Lahir } & \multicolumn{2}{|c|}{21 hari } & \multicolumn{2}{|c|}{35 hari } & \multirow{2}{*}{$\begin{array}{l}\text { Produksi susu } \\
\text { (g/ekor/21 hari) }\end{array}$} \\
\hline & & SD & & SD & & SD & \\
\hline $1 / 0$ & 453,33 & 57,19 & 1.798 & 109,96 & 3.900 & 882,1 & 1.414 \\
\hline $2 / 50$ & 509,58 & 50,87 & 2.287 & 218,77 & 4.740 & 1.207 & 1.660 \\
\hline $3 / 100$ & 512,56 & 39,34 & 2.134 & 239,56 & 4.591 & 1.134 & 1.585 \\
\hline $4 / 150$ & 484,82 & 56,97 & 1.909 & 323,36 & 4.206 & 1.177 & 1.391 \\
\hline $5 / 200$ & 480,55 & 30,62 & 2.096 & 175,19 & 4.493 & 983 & 1.566 \\
\hline $6 / 250$ & 455,97 & 26,80 & 1.990 & 267,88 & 3.925 & 81 & 1.426 \\
\hline $7 / 300$ & 484,41 & 54,22 & 2.060 & 366,74 & 4.264 & 744,14 & 1.477 \\
\hline Kecambah & 468,33 & 47,14 & 2.097 & 317,25 & & & \\
\hline
\end{tabular}

Tabel 7. Bobot karkas dan organ dalam kelinci jantan $(\mathrm{g})$

\begin{tabular}{lccccccc}
\hline \hline Perlakuan & $\begin{array}{c}\text { Bobot } \\
\text { potong }\end{array}$ & $\begin{array}{c}\text { Bobot } \\
\text { karkas }\end{array}$ & $\begin{array}{c}\text { Bobot kepala }+ \\
\text { kaki }\end{array}$ & $\begin{array}{c}\text { Bobot } \\
\text { hati }\end{array}$ & $\begin{array}{c}\text { Bobot } \\
\text { ginjal }\end{array}$ & $\begin{array}{c}\text { Bobot jeroan } \\
\text { lainnya }\end{array}$ & $\begin{array}{c}\text { Bobot kulit }+ \\
\text { bulu }\end{array}$ \\
\hline $1 / 0$ & 3.058 & 1.656 & 166,67 & 53,00 & $21,67^{\mathrm{b}}$ & 300,67 & 229,33 \\
$2 / 50$ & 2.826 & 1.448 & 137,67 & 55,67 & $21,67^{\mathrm{b}}$ & 214,33 & 311,67 \\
$3 / 100$ & 2.945 & 1.503 & 381,67 & 33,00 & $15,00^{\mathrm{a}}$ & 206,67 & 228,67 \\
$4 / 150$ & 2.896 & 1.503 & 141,00 & 33,00 & $11,00^{\mathrm{a}}$ & 180,33 & 149,67 \\
$5 / 200$ & 2.807 & 1.453 & 255,33 & 29,67 & $6,67^{\mathrm{a}}$ & 152,66 & 240,67 \\
$6 / 250$ & 2.932 & 1.515 & 253,00 & 30,00 & $17,00^{\mathrm{ab}}$ & 222,00 & 229,00 \\
$7 / 300$ & 3.097 & 1.645 & 284,33 & 56,33 & $9,67^{\mathrm{a}}$ & 171,00 & 142,33 \\
\hline
\end{tabular}

Superskrip yang berbeda menunjukkan berbeda nyata $(\mathrm{P}>0,05)$

\section{KESIMPULAN}

Suplementasi vitamin E pada pakan kelinci memberikan hasil yang baik terhadap produksi kelinci dilihat dari LS yang dihasilkan, susu yang dihasilkan dan terhadap kinerja baik efisiensi pakan ataupun pertambahan bobot badan. Jumlah kematian selama pemeliharaan di bawah 10\%. Suplementasi vitamin E pada pakan kelinci sebesar 50-100 $\mathrm{mg} / \mathrm{kg}$ pakan dapat memperbaiki kinerja serta produksi kelinci. Kebutuhan vitamin E dalam ransum kelinci yang baik untuk pertumbuhan dan produksi kelinci yaitu sekitar 200$300 \mathrm{mg} / \mathrm{kg}$ pakan.

\section{DAFTAR PUSTAKA}

Bernardini M, Dal Bosco A, Castellini C, Miggiano G. 1996. Dietary vitamin E supplementation in rabbit: Antioxidant capacity and meat quality. In: Lebas F, editor. Proceedings of the 6th World Rabbit Congress, Toulouse. Lempdes (France): Association Française de Cuniculture. p. 137-140. 
Castellini C, Mourvaki E, Dal Bosco A, Galli F. 2007. Vitamin E biochemistry and function: A case study in male rabbit. Rep Dom Anim. 42:248-256.

Cheeke PR. 1987. Rabbit nutrition and feeding. New York (US): Academic Press Inc. p. 295-302.

Cheeke PR, Patton NM, Lukefahr SD, McNitt JI. 1987. Rabbit production. Danville (US): The Interstate Printers and Publishers Inc.

El-Medany SA, Abdel-Khalek AM, Alla SAG, Shaaban FG, Abo-Warda MA, Mervat MA, Azoz AA, Samia ZM. 2012. Interaction between supplemental vitamin E and endogenous antioxidant enzymes of different rabbit genetic resources: 1-effect on performance during summer season. In: Proceedings 10th World Rabbit Congress. Sharm El- Sheikh, 3-6 September 2012. Sharm El- Sheikh (Egypt). p. 563-567.

Fernández-Carmona J, Blas E, Cervera C, Pascual JJ. 2006. The measure of milk rabbit. World Rabbit Sci. 14:58.

Fortun-Lamothe L, Gidenne T. 2000. The effects of size of suckled litter on intake behaviour, performance and health status of young and reproducing rabbits. Ann Zootech. 49:517-529.

Gad Alla SA, EI-Kelawy HM, Abo-Warda M. 2002. Effect of remating intervals and administration of vitamins $\mathrm{AD} 3+\mathrm{E}$ on some productive and reproductive performance in New Zealand White and Baladi red rabbits. Egyptian J Rabbit Sci. 12:203-218.

Kowalska D, Bielański P. 2009. Meat quality of rabbits fed a diet supplemented with fish oil and antioxidant. Anim Sci. 27.139-148.

Lebas F. 1969. Où en sont les essais d'alimentation des lapins aux granulés de luzerne déshydratée. Technical data from the Bureau de la nutrition animale et de l'élevage. Marseille. Doc. IT 436 D.

Lebas F. 1980. Les recherches sur l'alimentation du lapin: Évolution au cours des 20 dernières années et perspectives d'avenir. In: Proc. 2nd Word Rabbit Congress, 1980 April, Barcelona, Spain,Volume II. p. 1-17.

Maertens L, Lebas F, Szendrö ZS. 2006. Rabbit milk: A review of quantity, quality and nondietary affecting factors. World Rabbit Sci. 14:205-230.

NRC. 1977. Nutrient requirements of rabbits. Second Revised Edition. Washington DC (US): Committee on Animal Nutrition, National Research Council. National Academy of Sciences.

Scott ML, Nesheim MC, Young RJ. 1982. Nutrition of the chicken. 2nd ed. In: Scott ML, editor. New York: US): Assoc Publ Ithaca. p. 159-176.

Tawfeek ML, El-Gaafary MN. 1991. Evaluation of AI technique as compared to natural mating in association with some productive and reproductive traits rabbits. Egyptian J Rabbit Sci. 1:13.

Yamani KAO, El-Maghawry AM, Tawfeek ML, Soliman AM, Farghaly HM. 1994. Evaluation of the performance of three meat rabbit breeds recently introduced to Egypt. Litter weight and related traits. In: Proceeding of the 1st International Conference of Rabbit Production in Hot Climates. September 1994. Cairo (Egypt). 